\title{
Stable carbon and nitrogen isotope enrichment in primate tissues
}

\author{
Brooke E. Crowley $\cdot$ Melinda L. Carter $\cdot$ Sarah M. Karpanty $\cdot$ \\ Adrienne L. Zihlman • Paul L. Koch • Nathaniel J. Dominy
}

Received: 4 October 2009/ Accepted: 14 June 2010/Published online: 14 July 2010

(C) The Author(s) 2010. This article is published with open access at Springerlink.com

\begin{abstract}
Isotopic studies of wild primates have used a wide range of tissues to infer diet and model the foraging ecologies of extinct species. The use of mismatched tissues for such comparisons can be problematic because differences in amino acid compositions can lead to small isotopic
\end{abstract}

Communicated by Scott McWilliams.

Electronic supplementary material The online version of this article (doi:10.1007/s00442-010-1701-6) contains supplementary material, which is available to authorized users.

B. E. Crowley $(\bowtie) \cdot$ N. J. Dominy

Department of Ecology and Evolutionary Biology,

University of California, 1156 High Street, Santa Cruz,

CA 95064, USA

e-mail: bcrowley@pmc.ucsc.edu

N. J. Dominy

e-mail: njdominy@ucsc.edu

M. L. Carter

School of Medicine, Southern Illinois University, 409 West Carpenter Street, Springfield, IL 62702, USA

e-mail: mcarter3@siumed.edu

\section{S. M. Karpanty}

Department of Fisheries and Wildlife Sciences,

Virginia Polytechnic Institute and State University,

150 Cheatham Hall, Blacksburg, VA 24061, USA

e-mail: karpanty@vt.edu

\section{A. L. Zihlman · N. J. Dominy}

Department of Anthropology, University of California,

1156 High Street, Santa Cruz, CA 95064, USA

e-mail: azihlman@ucsc.edu

\section{P. L. Koch}

Department of Earth and Planetary Sciences,

University of California, 1156 High Street,

Santa Cruz, CA 95064, USA

e-mail: pkoch@pmc.ucsc.edu differences between tissues. Additionally, physiological and dietary differences among primate species could lead to variable offsets between apatite carbonate and collagen. To improve our understanding of the isotopic chemistry of primates, we explored the apparent enrichment $\left(\varepsilon^{*}\right)$ between bone collagen and muscle, collagen and fur or hair keratin, muscle and keratin, and collagen and bone carbonate across the primate order. We found that the mean $\varepsilon^{*}$ values of proteinaceous tissues were small $(\leq 1 \%)$, and uncorrelated with body size or phylogenetic relatedness. Additionally, $\varepsilon^{*}$ values did not vary by habitat, sex, age, or manner of death. The mean $\varepsilon^{*}$ value between bone carbonate and collagen $(5.6 \pm 1.2 \%$ ) was consistent with values reported for omnivorous mammals consuming monoisotopic diets. These primate-specific apparent enrichment values will be a valuable tool for cross-species comparisons. Additionally, they will facilitate dietary comparisons between living and fossil primates.

Keywords Stable isotope $\cdot$ Keratin $\cdot$ Muscle $\cdot$ Collagen · Apatite $\cdot$ Carbonate

\section{Introduction}

Stable isotope ratios in animal tissues vary with diet, habitat, and environmental conditions, and are often used to assess the foraging ecology and habitat preferences of living and extinct species (West et al. 2006). These studies have varied methodologically, using a range of tissues. For instance, the diets of wild primates have been assessed using isotope values from hair (e.g., Schoeninger et al. 1997, 2006), tooth enamel (e.g., Codron et al. 2005; Fourie et al. 2008; Smith et al. 2010), bone (e.g., Ambrose and DeNiro 1986; Thackeray et al. 1996; Smith et al. 2010), 
and feces (e.g., Codron et al. 2006). These data, in turn, have been used to inform paleo-ecological models of extinct species, including early human ancestors (e.g., Thackeray et al. 1996; Codron et al. 2005; Sponheimer et al. 2006, 2010). Due to tissue preservation issues, these studies have frequently had to use different tissues in their modern and ancient comparisons.

Although the availability and state of preservation of specimens are practical constraints, it can be problematic to compare the isotopic composition of different tissues for two reasons. First, carbon and nitrogen isotope values of proteinaceous tissues can differ within an animal because each tissue has a unique amino acid (AA) composition, and the AAs themselves vary isotopically (e.g., Hare et al. 1991; Styring et al. 2010). Second, when studying fossils, researchers generally use the carbonate fraction of biological apatite. The isotopic difference [hereafter termed apparent enrichment, $\varepsilon^{*}$ (defined below)] between carbon in organic tissues, such as collagen in bone or dentin, and carbon in the carbonate in bone or tooth apatite varies with both digestive physiology and dietary macromolecular composition (reviewed in Hedges 2003).

A wide range of dietary and gut physiological adaptations among primates could lead to differences in $\varepsilon^{*}$ values for both carbon and nitrogen that could in turn confound ecological or paleoecological interpretations. Many experiments have been conducted on rodents and pigs, but most were focused on carbon isotope differences between carbonate and collagen. Scarcely any work has examined the differences between proteinaceous tissues, let alone unconventional taxa. For instance, only one published study has focused on nonhuman primates (O'Regan et al. 2008) (Table 1). Accordingly, we compared the carbon and nitrogen isotope values in keratin, muscle protein, bone collagen, and bone carbonate (carbon only) for a diverse group of primate species (Table 2). We expected that differences in AA composition would drive $\varepsilon^{*}$ variation among proteinaceous tissues for both carbon and nitrogen, but that these differences would be small and consistent across individuals and species. We also expected that $\varepsilon^{*}$ values for carbonate versus collagen carbon would vary among species as a function of both diet and digestive physiology, and factors that correlate with these variables (body size, habitat, etc.).

\section{Background on variation in $\varepsilon^{*}$ values}

Variation among proteinaceous tissues

The isotopic values of proteinaceous tissues within an individual could vary because (1) the concentration of different AAs varies among tissues, and (2) the isotopic composition of individual amino acids (AAs) shows considerable variation (19.9\%o average range for C, $24.4 \%$ average range for N; Fig. 1). This variability relates to isotopic differences among ingested AAs, differences in mammalian biosynthetic pathways for non-essential AAs, and the extent to which a mammal either synthesizes or incorporates a particular AA from its diet. This is a complex subject, but a few patterns have emerged. For carbon, glycine and metabolically-related AAs (serine, cysteine) are often ${ }^{13} \mathrm{C}$-enriched relative to other non-essential AAs, whereas essential AAs track variation in ingested AAs (Hare et al. 1991; Fogel and Tuross 2003; Jim et al. 2006). For nitrogen, there are a suite of AAs that are ${ }^{15} \mathrm{~N}$-enriched with each trophic step (e.g., glutamate, asparate, alanine, isoleucine, valine, proline) and others that do not enrich (e.g., phenylalanine, lysine, glycine) (McClelland and Montoya 2002; Popp et al. 2007). Muscle (myosin) in humans, and most likely other primates, is dominated by ${ }^{15} \mathrm{~N}$-enriched glutamate and alanine (Bergström et al. 1974). Collagen is mainly composed of ${ }^{13} \mathrm{C}$-enriched glycine $(33 \%)$ and ${ }^{15} \mathrm{~N}$-enriched aspartate $(5 \%)$, glutamate $(7 \%)$, and proline and hydroxyproline $(33 \%)$. Primate keratin is dominated by ${ }^{13} \mathrm{C}$-enriched cysteine $(\sim 12-17 \%)$ and serine $(\sim 10 \%)$, and ${ }^{15} \mathrm{~N}$-enriched glutamate $(\sim 17 \%)$ (Hrdy and Baden 1973; O'Connell et al. 2001).

\section{Variation in carbonate-apatite $\varepsilon^{*}$ values}

The measured mean carbon isotope difference between carbon in carbonate and collagen $\left(\varepsilon^{13 *}\right.$ carbonate-collagen $)$ is $\sim 7 \%$ or greater in wild large-bodied herbivores and $\sim 3 \%$ o in faunivorous animals (Table 1). There are two potential explanations for this difference that are not mutually exclusive. First, it could result from differences in dietary macromolecular composition (i.e., protein, lipid, and carbohydrate), which affect both diet-to-protein and diet-tocarbonate $\varepsilon^{*}$ values due to differing $\delta^{13} \mathrm{C}$ values among macromolecules, and differential routing of macromolecules to particular tissues. Second, it could result from differences in how animals digest plant and animal matter, which only affect diet-to-carbonate $\varepsilon^{*}$ values (Hedges 2003).

Apatite carbonate, which likely forms in isotopic equilibrium with blood bicarbonate, reflects carbon in bulk diet (i.e., a proportional mixture of carbon from all assimilated macronutrients) (Ambrose and Norr 1993; Passey et al. 2005). The isotopic composition of consumer proteins reflects that of dietary proteins (Ambrose and Norr 1993; Tieszen and Fagre 1993; Ambrose et al. 1997; Howland et al. 2003; Jim et al. 2004, 2006). Essential AAs must be routed directly from the diet, but depending on dietary protein concentration, non-essential AAs can also be routed into consumer tissues or synthesized using carbon from dietary carbohydrates, lipids and proteins. Theoretically, 
Table 1 Tissue-tissue carbon and nitrogen fractionation values from previous research on mammals

\begin{tabular}{|c|c|c|c|c|c|c|c|c|}
\hline Taxon & & Diet $^{a}$ & $n$ & $\Delta^{13} \mathrm{C}$ & Range & $\Delta^{15} \mathrm{~N}$ & Range & References \\
\hline \multicolumn{9}{|c|}{ Collagen-keratin } \\
\hline Mouse & Captive & Mixed & 72 & $2.9 \pm 2.2$ & $1.1,7.1^{\mathrm{b}}$ & & & 1 \\
\hline Mouse & Captive & Uniform & 24 & $2.5 \pm 0.3$ & $2.3,2.7^{\mathrm{b}}$ & & & 1 \\
\hline Wolf & Captive & Uniform & 18 & $0.4 \pm 0.8$ & $-0.9,2.3$ & $0.3 \pm 0.7$ & $-1.0,1.7$ & 2 \\
\hline Human & Modern & Mixed & 8 & $1.5 \pm 0.5$ & $0.8,2.2$ & $0.9 \pm 0.2$ & $0.7,1.1$ & 3 \\
\hline Macaque & Wild & Mixed $^{\mathrm{c}}$ & 13 & $0.1 \pm 1.1$ & $-1.5,1.0^{\mathrm{b}}$ & $0.4 \pm 0.3$ & $-0.3,1.1$ & 5 \\
\hline \multicolumn{9}{|c|}{ Collagen-muscle } \\
\hline Mouse & Captive & Mixed & 72 & $2.4 \pm 0.4$ & $1.7,2.9^{\mathrm{b}}$ & & & 1 \\
\hline Mouse $^{\mathrm{d}}$ & Captive & Mixed & 2 & $3.7 \pm 0.1$ & $3.6,3.8$ & & & 1 \\
\hline Mouse & Captive & Uniform & 24 & $2.2 \pm 0.8$ & $1.6,2.7^{\mathrm{b}}$ & & & 1 \\
\hline Mouse $^{\mathrm{d}}$ & Captive & Uniform & 6 & $2.4 \pm 0.6$ & $1.8,3.5$ & & & 1 \\
\hline Sheep & Domestic & Mixed & 2 & $4.1 \pm 0.1$ & $4.0,4.1$ & & & 6 \\
\hline Pig & Domestic & Uniform & 20 & $1.1 \pm 1.6$ & $-0.1,2.2^{\mathrm{b}}$ & $0.9 \pm 0.6$ & $0.5,1.3$ & 7 \\
\hline Wolf & Captive & Uniform & 18 & $1.5 \pm 0.7$ & $0.4,3.1$ & $-0.5 \pm 0.8$ & $-1.8,1.8$ & 2 \\
\hline Gemsbok & Wild & Mixed & 1 & 0.7 & & & & 6 \\
\hline Hartabeest & Wild & Mixed & 1 & 1.9 & & & & 6 \\
\hline Impala & Wild & Mixed & 1 & 1.7 & & & & 6 \\
\hline Kudu & Wild & Uniform & 2 & $2.4 \pm 0.6$ & $1.9,2.8$ & & & 6 \\
\hline Springbok & Wild & Mixed & 3 & $2.4 \pm 0.6$ & $1.8,3.0$ & & & 6 \\
\hline Warthog & Wild & Mixed & 1 & 1.7 & & & & 6 \\
\hline \multicolumn{9}{|c|}{ Muscle-keratin } \\
\hline Gerbil & Captive & Mixed & 37 & $-2.3 \pm 0.7$ & $-3.6,-1.3^{\mathrm{b}}$ & & & 8 \\
\hline Mouse & Captive & Mixed & 72 & $0.5 \pm 2.1$ & $-1.3,4.5^{\mathrm{b}}$ & & & 1 \\
\hline Mouse & Captive & Uniform & 24 & $0.4 \pm 0.5$ & $0.0,0.7^{\mathrm{b}}$ & & & 1 \\
\hline Mouse & Captive & All & & $-2.9^{\mathrm{e}}$ & & & & 9 \\
\hline Mouse & Captive & All & 18 & & & $0.3^{\mathrm{e}}$ & & 10 \\
\hline Pig & Domestic & Uniform & 5 & 1.8 & & -0.1 & & 11 \\
\hline Fox & Captive & Mixed & 20 & $-1.5^{\mathrm{f}}$ & & $0.2 \pm 0.1$ & $0.1,0.2^{\mathrm{b}}$ & 12 \\
\hline Wolf & Captive & Uniform & 19 & $-1.2 \pm 0.4$ & $-2.2,0.5$ & $0.8 \pm 0.5$ & $-0.2,1.5$ & 2 \\
\hline \multicolumn{9}{|c|}{ Carbonate-collagen } \\
\hline Mouse & Captive & Mixed & 72 & $4.7 \pm 3.0$ & $1.3,8.7^{\mathrm{b}}$ & & & 1 \\
\hline Rat & Captive & Mixed & 20 & $4.2 \pm 4.4$ & $-0.8,11.1^{\mathrm{b}}$ & & & 13 \\
\hline Rat & Captive & Mixed & $18-60$ & $7.2 \pm 4.6$ & $1.3,11.3^{\mathrm{b}}$ & & & 14 \\
\hline Mouse & Captive & Uniform & 24 & $5.9 \pm 1.1$ & $5.1,6.7^{\mathrm{b}}$ & & & 1 \\
\hline Rat & Captive & Uniform & 8 & $5.0 \pm 0.6$ & $4.5,6.0$ & & & 13 \\
\hline Rat & Captive & Uniform & $3-10$ & 5.7 & & & & 14 \\
\hline Pig & Domestic & Mixed & 5 & $7.5 \pm 1.0$ & $6.4,9.1$ & & & 15 \\
\hline Pig & Domestic & Uniform & 1 & 6.0 & & & & 15 \\
\hline Herbivore & Wild & All & & 6.8 & & & & 16 \\
\hline Giraffe & Wild & Uniform & 4 & $6.9 \pm 0.3$ & $6.7,7.4$ & & & 18,19 \\
\hline Hartabeest & Wild & Mixed & 1 & 8.4 & & & & 18 \\
\hline Topi & Wild & Uniform & 1 & 10.3 & & & & 19 \\
\hline Deer & Wild & Mixed & 1 & 6.8 & & & & 18 \\
\hline Reindeer & Wild & Uniform & 8 & $8.5 \pm 0.8$ & $7.0,9.5$ & & & 20 \\
\hline Llama & Wild & Uniform & 6 & $7.1 \pm 0.3$ & $6.6,7.3$ & & & 17 \\
\hline Hippo & Wild & Mixed & 4 & $6.6 \pm 0.7$ & $5.8,7.5$ & & & 18,19 \\
\hline Zebra & Wild & Mixed & 2 & $9.0 \pm 1.1$ & $8.2,9.7$ & & & 18,19 \\
\hline Omnivore & Wild & All & & 5.2 & & & & 16 \\
\hline
\end{tabular}


Table 1 continued

\begin{tabular}{llllcccc}
\hline Taxon & & Diet & $n$ & $\Delta^{\mathrm{a}}{ }^{13} \mathrm{C}$ & Range & $\Delta^{15} \mathrm{~N}$ & Range \\
\hline Macaque & Wild & Mixed & 11 & $5.7 \pm 0.5$ & $5.0,6.1$ & 5 \\
Carnivore & Wild & All & & 4.3 & & 16 \\
Fur Seal & Wild & Uniform & 2 & $2.2 \pm 0.8$ & $1.6,2.7$ & 16 \\
Harbor Seal & Wild & Uniform & 4 & $2.4 \pm 1.1$ & $1.6,4.1$ & 20 \\
Harp Seal & Wild & Uniform & 4 & $3.6 \pm 1.1$ & $2.2,4.5$ & 20 \\
\hline
\end{tabular}

References: (1) Tieszen and Fagre (1993); (2) Fox-Dobbs et al. (2007); (3) O’Connell et al. 2001; (4) O'Regan et al. (2008); (5) Vogel (1978); (6) Hare et al. (1991); (7) Tieszen et al. (1983); (8) DeNiro and Epstein (1978); (9) DeNiro and Epstein (1981); (10) Nardoto et al. (2006); (11) Roth and Hobson (2000); (12) Jim et al. (2004); (13) Ambrose and Norr (1993); (14) Howland et al. (2003); (15) Lee-Thorp et al. (1989); (16) Schoeninger and DeNiro (1982); (17) Sullivan and Krueger (1981); (18) Kellner and Schoeninger (2007); (19) Nelson et al. (1986)

"Whenever possible, animal diets were divided into "uniform" (consumed all $\mathrm{C}_{3}$ or all $\mathrm{C}_{4}$ ) or "mixed" (consumed a combination of $\mathrm{C}_{3}, \mathrm{C}_{4}$ or marine). Otherwise, we use the category "All". Diets for wild animals, which were inferred by the primary authors from each study, were considered mixed if the primary diet source (e.g., $\mathrm{C}_{3}$ or $\mathrm{C}_{4}$ ) was $\leq 90 \%$

b Standard deviations and ranges were calculated for captive groups fed similar diets, or wild groups living in different regions

${ }^{c}$ Dietary information is not available for these animals. The authors argue that collagen $\delta^{13} \mathrm{C}$ values suggest that some individuals may have consumed some $\mathrm{C}_{4}$ resources. However, apatite $\delta^{13} \mathrm{C}$ values do not support $\mathrm{C}_{4}$ consumption. Because no comparative plant data are available from the respective habitats, it is not possible to validate or refute $\mathrm{C}_{4}$ consumption

${ }^{\mathrm{d}}$ Nursing mothers $(n=2)$ and suckling babies $(n=6)$

e Mean $\Delta$ values estimated using Datathief 12.0

${ }^{\mathrm{f}}$ Standard deviation and range were not presented

animals on high protein diets (e.g., faunivores) should route more carbon from dietary protein to tissue protein, whereas animals on low protein diets (e.g., many herbivores) should synthesize more non-essential amino acids de novo, incorporating carbon from lipid and carbohydrate as well as protein into their tissue protein (Fogel and Tuross 2003; Hedges 2003; Martínez del Rio and Wolf 2005). Additionally, because assimilation of ${ }^{13} \mathrm{C}$-depleted lipids could lower apatite $\delta^{13} \mathrm{C}$ values without affecting body protein $\delta^{13} \mathrm{C}$ values (due to routing), faunivores with fat-rich diets (such as seals) should have even smaller $\varepsilon^{13 *}$ carbonate-collagen values (Krueger and Sullivan 1984; Lee-Thorp et al. 1989; Hedges 2003). Provided that these animals consume monoisotopic diets (e.g., only $\mathrm{C}_{3}$-derived foods), this should result in larger and smaller $\varepsilon^{13 *}$ carbonate-collagen values in herbivores and carnivores, respectively. Whereas, all primates consume a dominantly vegetarian diet (Milton 1987), some genera such as Cebus, Daubentonia, Galago, and Microcebus can consume considerable amounts of animal matter (Milton and May 1976). Based on these dietary differences, we might anticipate that these taxa should have lower $\varepsilon^{13 *}$ carbonate-collagen values than more herbivorous species. Importantly, controlled diet studies demonstrate that animals fed a mixture of $\mathrm{C}_{3}, \mathrm{C}_{4}$ and marine-derived macronutrients exhibit substantial variation in $\varepsilon^{13 *}$ carbonate-collagen values (Table 1 ). Mixed diets are unlikely in the majority of wild primate species. However, this could be important for captive primates if they consume manufactured pellets containing a mix of $\mathrm{C}_{3}$ and $\mathrm{C}_{4}$ foods.

The isotopic composition of carbonate in bone apatite is also predicted to vary with the extent to which complex carbohydrates are fermented in the gut (Hedges 2003). During fermentation, bacteria break down structural carbohydrates, releasing appreciable amounts of hydrogen, $\mathrm{CO}_{2}$, and volatile fatty acids (VFA) (Jensen 1996). Some of the released $\mathrm{CO}_{2}$ can be reduced to form $\mathrm{CH}_{4}$. This process discriminates heavily against ${ }^{13} \mathrm{C}$, leaving the remaining $\mathrm{CO}_{2}{ }^{13} \mathrm{C}$ enriched (Metges et al. 1990; Schulze et al. 1997). If even a small amount of this ${ }^{13} \mathrm{C}$-enriched $\mathrm{CO}_{2}$ enters the blood bicarbonate pool, it could increase the $\delta^{13} \mathrm{C}$ value of apatite carbonate which forms from this pool, thus increasing $\varepsilon^{13 *}$ carbonate-diet and $\varepsilon^{13 *}$ carbonate-collagen values (Passey et al. 2005). The $\delta^{13} \mathrm{C}$ value of collagen is not affected by methane production (e.g., Metges et al. 1990).

Ruminants have been shown to produce copious amounts of methane and large $\Delta_{\text {carbonate-collagen }}$ values (e.g., Crutzen et al. 1986; Metges et al. 1990; Table 1). Although some large, non-ruminant herbivores such as camelids and horses also exhibit high levels of methane production and elevated $\Delta_{\text {carbonate-collagen }}$ values (Crutzen et al. 1986; Langer 1987; Table 1), methane production in most simple-stomached species is trivial, despite the presence of methanogenic bacteria (Crutzen et al. 1986; Jensen 1996). Acidic conditions in the stomachs and small intestines of simple-stomached animals may prevent methane production, but neutral 
Table 2 Species, body mass of males and females, and provenience of specimens included in this study

\footnotetext{
a Mass estimates are based on Smith and Jungers 1997 (H. sapiens $=$ Danish values), excepting $M$. griseorufus (Génin 2008)

b Sources: (1) Duke Lemur Center; (2) S.M. Karpanty, Ranomafana National Park, Madagascar, samples collected from raptor nests; (3) Beza Mahafaly Special Reserve; Madagascar, (4) L.R. Godfrey; (5) P.C. Wright; (6) Santa Rosa National Park, Costa Rica, (7) El Zota Research Station, Costa Rica, (8) K.E. Glander; (9) M.E. Carter; (10) Department of Anthropology, UC Santa Cruz; (11) O'Regan et al. 2008; (12) O'Connell et al. 2001
}

\begin{tabular}{|c|c|c|c|c|}
\hline \multirow[t]{2}{*}{ Family and species } & \multicolumn{2}{|c|}{ Body mass $(\mathrm{kg})^{\mathrm{a}}$} & \multirow[t]{2}{*}{ Type } & \multirow[t]{2}{*}{ Provenance } \\
\hline & Male & Female & & \\
\hline \multicolumn{5}{|l|}{ Lorisoidea } \\
\hline Galago senegalensis mohili & 0.2 & 0.2 & Captive & 1 \\
\hline \multicolumn{5}{|l|}{ Lemuroidea } \\
\hline Avahi laniger & 1.0 & 1.3 & Wild & 2 \\
\hline Cheirogaleus major & 0.4 & 0.4 & Wild & 2 \\
\hline D. madagascariensis & 2.6 & 2.5 & Captive & 1 \\
\hline Eulemur fulvus albifrons & 2.0 & 2.2 & Captive & 1 \\
\hline E. fulvus rufus & 2.2 & 2.3 & Wild & 4 \\
\hline E. macaco flavifrons & 2.4 & 2.5 & Captive & 1 \\
\hline E. mongoz & 1.6 & 1.6 & Captive & 1 \\
\hline L. catta & 3.6 & 3.5 & Captive & 1 \\
\hline Indri indri & 5.6 & 6.3 & Wild & 4 \\
\hline Microcebus griseorufus & 0.05 & 0.06 & Wild & 3 \\
\hline M. murinus & 0.1 & 0.1 & Captive & 1 \\
\hline M. rufus & 0.1 & 0.1 & Wild & 2 \\
\hline Propithecus coquereli verreauxi & 3.7 & 4.3 & Captive & 1 \\
\hline P. diadema & 5.9 & 6.3 & Wild & \\
\hline P. verreauxi & 3.3 & 3.0 & Wild & 3 \\
\hline V. variagata & 3.5 & 3.5 & Captive & 1 \\
\hline \multicolumn{5}{|l|}{ Ceboidea } \\
\hline Alouatta paliatta & 6.5 & 4.2 & Wild & $6-8$ \\
\hline A. geoffroyi & 7.8 & 7.3 & Wild & 6,7 \\
\hline C. capucinus & 3.7 & 2.5 & Wild & 6,7 \\
\hline \multicolumn{5}{|l|}{ Cercopithecoidea } \\
\hline Cercopithecus ascanius & 3.7 & 2.9 & Wild & 9 \\
\hline Chlorocebus aethiops & 5.0 & 3.5 & Captive & 10 \\
\hline Lophocebus albigena & 8.3 & 6.0 & Wild & 9 \\
\hline M. mulatta & 11 & 8.8 & Wild & 11 \\
\hline Papio anubis & 25.1 & 13.3 & Wild & 9 \\
\hline P. badius & 8.4 & 8.2 & Wild & 9 \\
\hline S. entellus & 19.2 & 14.8 & Captive & 10 \\
\hline \multicolumn{5}{|l|}{ Hominoidea } \\
\hline Gorilla gorilla & 170.4 & 71.5 & Captive & 10 \\
\hline Homo sapiens & 72.1 & 62.1 & Captive & 12 \\
\hline Hylobates moloch & 6.6 & 6.3 & Captive & 10 \\
\hline Pan paniscus & 42.7 & 33.7 & Captive & 10 \\
\hline P. troglodytes & 59.7 & 45.8 & Wild & 9 \\
\hline P. troglodytes & 59.7 & 45.8 & Captive & 10 \\
\hline Pongo pygmaeus & 78.5 & 35.8 & Captive & 10 \\
\hline
\end{tabular}

conditions in the posterior portions of the colon may be more amenable (Jensen 1996). Nevertheless, because gases formed near the end of the gastro-intestinal tract do not likely have time to diffuse into the blood stream, ${ }^{13} \mathrm{C}$-depleted methane produced in the posterior portions of the colon have a negligible effect on apatite $\delta^{13} \mathrm{C}$ values. Little is known about methane production in nonhuman primates. For the most part, it is doubtful that nonhuman primates would differ substantially from other simplestomached animals. However, colobine monkeys could provide a possible exception. This subfamily of Old World Primates, has been likened to ruminants because they have large sacculated stomachs to facilitate microbial fermentation of leaves (Kay and Davies 1994). Primates with adaptations for caeco-colic fermentation, such as Alouatta palliata (Lambert 1998), may also have increased levels of 

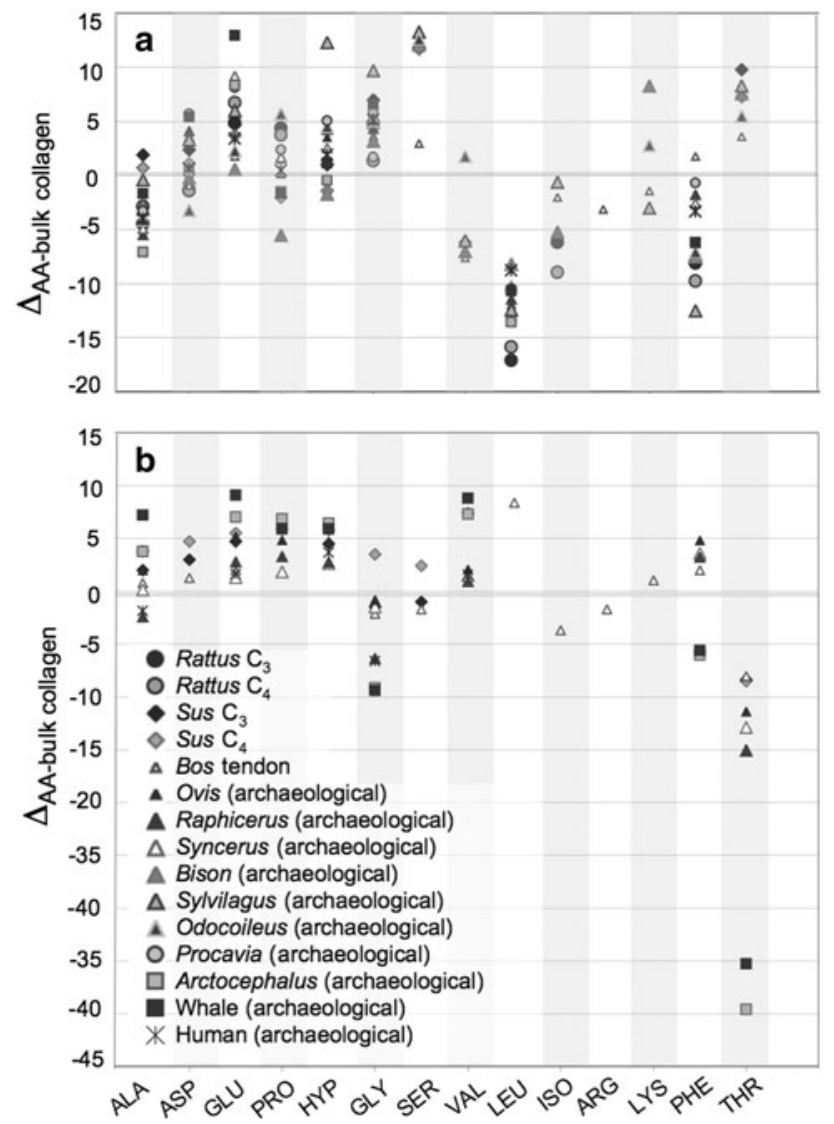

Fig. 1 Fractionation between individual amino acids and bulk collagen and tendon (Bos only) for carbon (a) and nitrogen (b) in mammals. The number of individuals for each taxon is provided in parentheses. Carbon data sources: Bos (1) (Hare and Estep 1983), Rattus $\left(\mathrm{C}_{3}=2, \mathrm{C}_{4}=2\right)$ (Jim et al. 2006), Sus $\left(\mathrm{C}_{3}=4, \mathrm{C}_{4}=4\right)$ (Hare et al. 1991), archaeological Bison (1), Oidocoleus(1), and Sylvilagus (1) (Fogel and Tuross 2003), and archaeological Procavia (2), Syncerus (2), Ovis (3), Raphicerus (2), Arctocephalus (2), whale (2), and humans (32) (Fogel and Tuross 2003; Corr et al. 2005). Nitrogen data sources: Bos (1) (Hare and Estep 1983), Sus $\left(C_{3}=4\right.$, $\mathrm{C}_{4}=4$ ) (Hare et al. 1991), archaeological Syncerus (2), Ovis (2), Raphicerus (2), Arctocephalus (2), whale (1), and humans (11) (Styring et al. 2010)

methane production. This possibility is strengthened by the observation that horses, which are also caeco-colic fermenters, have $\Delta_{\text {carbonate-collagen }}$ values (Sullivan and Krueger 1981; Kellner and Schoeninger 2007, Table 1).

\section{Isotopic terminology}

Isotope ratios are typically presented using $\delta$ notation, where

$\delta^{\mathrm{H}} \mathrm{X}=\left(\left(R_{\text {sample }} / R_{\text {standard }}\right)-1\right) \times 1,000$

and $R$ is the heavy-to-light isotope ratio in element $\mathrm{X}$. It is expressed in parts per thousand (i.e., per mil, \%o). Carbon isotope values are reported relative to the V-PDB standard (a marine carbonate); nitrogen isotope values are relative to AIR. The offset, or fractionation, between two substances (a and b) is often expressed using $\Delta$ notation (Martínez del Rio et al. 2009), where

$\Delta^{\mathrm{H}} \mathrm{X}_{\mathrm{a}-\mathrm{b}}=\delta^{\mathrm{H}} \mathrm{X}_{\mathrm{a}}-\delta^{\mathrm{H}} \mathrm{X}_{\mathrm{b}}$

$\delta$ values are trivial to calculate and accurate so long as the differences in $\delta$ values among tissues are small. However, $\Delta$ values become less accurate as the differences in $\delta$ values among tissues increase. We choose to use alternative expressions, the fractionation factor $(\alpha)$ and isotope enrichment values $(\varepsilon)$, which provide exact solutions and are not limited by the isotopic scale on which they are calculated (e.g., PDB vs. SMOW). $\Delta$ and $\varepsilon$ values are nearly identical when isotopic differences among tissues are $<1-2 \%$, but the two increasingly differ with increasing isotopic differences among tissues. When tissues are $\geq 10 \%, \Delta$ and $\varepsilon$ values can differ by as much as $0.5 \%$ (Cerling and Harris 1999). To calculate $\varepsilon$, we first calculate $\alpha$.

$\alpha_{\mathrm{a}-\mathrm{b}}=\left(\delta^{\mathrm{H}} \mathrm{X}_{\mathrm{a}}+1,000\right) /\left(\delta^{\mathrm{H}} \mathrm{X}_{\mathrm{b}}+1,000\right)$

$\varepsilon_{\mathrm{a}-\mathrm{b}}=\left(\alpha_{\mathrm{a}-\mathrm{b}}-1\right) \times 1,000$

In animals, the observed $\alpha$ value between two tissues, or between diet and a tissue, is the net result of a large range of biochemical and transport phenomena, not the simple equilibrium and kinetic reactions for which isotopic fractionation factors are typically measured. We recognize the complexity of these physiological systems by denoting these as apparent fractionation factors $\left(\alpha^{*}\right)$ and apparent enrichment values $\left(\varepsilon^{*}\right)$. When referring to values for a particular element, we will use $\varepsilon^{13 *}$ for carbon and $\varepsilon^{15 *}$ for nitrogen. Note that the sign of enrichment is dependent on which substance is in the numerator in Eq. 3. Hence $\varepsilon^{*}$ (and $\alpha^{*}$ and $\Delta$ ) values must always be reported with subscripts or explicitly defined.

\section{Materials and methods}

\section{Sample acquisition}

Tissues from captive and wild primates were acquired from cadaveric and osteologic collections in museums, universities and research field stations (Table 2). With a few exceptions, the animals were in good health at the time of death. The main manner of death for captive animals was electrocution, drowning, or short-term illness. However, a few individuals endured chronic illness, and some died at an advanced age. The manner of death for wild animals was largely unknown, but we were able to attribute the deaths of several individuals to predation or automobile 
impact (Electronic supplementary material, ESM, Table S1). The acquisition and analysis of tissues was approved by the Chancellor's Animal Research Committee, University of California, Santa Cruz (approval nos. DOMIN 07.01 and ZIHL 97.12), and the Institutional Animal Care and Use Committee, Stony Brook University (approval no. 20001142). We combined our data with data from three preexisting datasets (Kibale primates: Carter, 2001; modern humans: O'Connell et al. 2001; Macaca mulatta: O'Regan et al. 2008).

Sample preparation and analysis

For each specimen, soft tissues were separated and lyophylized. Bone was defleshed; $20 \mathrm{mg}$ were ground for the analysis of carbonate in bone apatite and $50 \mathrm{mg}$ were crushed coarsely for extraction of collagen. For protein analysis, bone samples were treated with $5 \mathrm{ml}$ of $0.5 \mathrm{~N}$ $\mathrm{HCl}$ for $72 \mathrm{~h}$ to remove the mineral fraction. Samples were rinsed $5 \times$ with water and dried. Lipids were removed from all proteinaceous tissues by repeated rinsing and sonication in $5 \mathrm{ml}$ aliquots of petroleum ether for $15 \mathrm{~min}$ intervals until all visible lipids were removed. Samples were then rinsed $5 \times$ with ultrapure water and lyophilized.

With the exception of keratin-which was cleaned, cut to $1 \mathrm{~mm}$ lengths, and homogenized—all soft tissue samples were powdered using a mortar and pestle. Approximately $700 \mu \mathrm{g}$ of ground soft tissue, homogenized keratin, or bone collagen were then sealed into tin boats and analyzed for $\delta^{13} \mathrm{C}$ and $\delta^{15} \mathrm{~N}$ values on a ThermoElectron (Finnigan) Delta + XP continuous flow system coupled to an elemental analyzer (EA) at the University of California, Santa Cruz (UCSC) Stable Isotope Laboratory. Analytical precision $( \pm 1 \mathrm{SD})$ based on 33 replicates of IAEA Acetanilide was $-29.6 \pm 0.1 \%$ for carbon and $1.1 \pm 0.1 \%$ for nitrogen. We ran replicate samples for a subset of our specimens to determine sample precision. The average difference between the absolute value of 14 duplicate tissue samples was $0.2 \pm 0.2 \%$ for carbon and $0.2 \pm 0.2 \%$ for nitrogen. The average difference between the absolute value of five triplicate samples was $0.3 \pm 0.1 \%$ and $0.3 \pm 0.3 \%$ for carbon and nitrogen, respectively.

Bone carbonate samples were prepared using a modified technique from Koch et al. (1997). To oxidize organic materials, $1 \mathrm{ml}$ of $30 \%$ laboratory-grade hydrogen peroxide $\left(\mathrm{H}_{2} \mathrm{O}_{2}\right)$ was added to $20 \mathrm{mg}$ of powdered sample and left for $48 \mathrm{~h}$, then rinsed $5 \times$ with ultrapure water. To remove non-lattice bound carbonate, samples were reacted for $24 \mathrm{~h}$ with $0.5 \mathrm{ml}$ of $1 \mathrm{M}$ acetic acid (buffered to $\mathrm{pH} 5.0$ with calcium acetate). Samples were again rinsed $5 \times$ with ultrapure water and lyophylized. For carbonate samples, $1.5 \mathrm{mg}$ of powdered bone were put into steel cups and dried at $65^{\circ} \mathrm{C}$ for $1 \mathrm{~h}$ under vacuum. The samples were then analyzed on a Micromass Optima gas source mass spectrometer integrated with an Isocarb automated carbonate device. Samples were dissolved in $100 \% \mathrm{H}_{3} \mathrm{PO}_{4}$ at $90^{\circ} \mathrm{C}$, with concurrent cryogenic distillation of $\mathrm{CO}_{2}$ and $\mathrm{H}_{2} \mathrm{O}$ and automated $\mathrm{CO}_{2}$ admittance to the mass spectrometer for analysis. Reaction time was set at $740 \mathrm{~s}$ and blanks were run between samples. Accuracy and precision $( \pm 1 \mathrm{SD})$ based on the international NBS 19 standard analyzed with samples was $\delta^{13} \mathrm{C}=2.1 \pm 0.1 \%$ o $(n=18)$, very close to the known value of $2.0 \%$. The average difference between the absolute value of 10 duplicate samples was $0.3 \pm 0.2 \%$.

\section{Data analysis}

We were not able to assess dietary composition or digestive physiology carefully for primates included in this study. Although it is tempting to divide primates into broad groups such as folivore, frugivore, or trophic omnivore, these dietary categories would likely be inaccurate for four reasons. First, the majority of primates are generalist primary consumers rather than strict folivores or frugivores. For example, the "frugivorous" lemur Varecia variagata can eat substantial amounts of leaves and fungus (A. Baden, personal communication). Conversely, the diet of Piliocolobus badius, a "folivorous" monkey, frequently contains fruit and flowers (Chapman et al. 2002a). Second, all primates have omnivorous tendencies (Fleagle 1999). In particular, many "frugivorous" primate species supplement their predominantly herbivorous diets either intentionally or inadvertently with insects or vertebrates. For example, among the "frugivorous" species, Hylobates lar and Lemur catta spend a substantial amount of time feeding on insects in addition to vegetation (Rowe 1996; Yamashita 2002), and Pan troglodytes consumes termites and red colobus monkeys (Boesch and Boesch-Achermann 2000). Third, primate diets can differ substantially between years and between localities (e.g., Chapman et al.2002a, b; González-Zamora et al. 2009). For example diets ranging from 49 to $87 \%$ leaves, and 13-49\% fruits have been reported for Mexican populations of A. palliata (Cristóbal-Azkarate and ArroyoRodríguez 2007). Finally, we know little about the diets of most of our captive individuals, including the degree to which they were provisioned with chow.

Instead, we used one-way analysis of variance (ANOVA) and Tukey post-hoc tests of honestly significant differences (HSD) to detect differences in $\varepsilon^{*}$ values among habitats (e.g., captive, dry, or moist habitat) that may correlate with diet quality. Diet and digestive physiology may covary with two other variables that we were able to assess: body size and phylogenetic relatedness. In general, diet quality decreases with increasing body size (e.g., Kleiber 1961). More folivorous primates have longer and 
more complex guts than frugivorous or insectivorous primates (Chivers and Hladik 1980), and primates that are more closely related should have more similar digestive physiology. We used Pearson correlation coefficients to determine if $\varepsilon^{*}$ values correlate with body mass, and we tested for the potential confounding effects of phylogenetic relatedness by using the primate phylogeny of BinindaEmonds et al. (2007) and the PDAP module of Mesquite version 2.5 (Maddison and Maddison 2008) to calculate phylogenetic independent contrasts.

Additionally, we used one-way ANOVA and Tukey HSD to detect differences in $\varepsilon^{*}$ values among manners of death (grouped into abrupt, short-term illness, long-term illness, and unknown). We used independent sample $t$ tests to detect differences in $\varepsilon^{*}$ values between sexes. Detailed age information for strepsirrhines from the Duke Lemur Center allowed us to calculate percent lifespan lived. We grouped these individuals into five equal age classes, and used oneway ANOVA and Tukey HSD to detect differences in $\varepsilon^{*}$ values among age classes. Although there are no theoretical expectations for $\varepsilon^{*}$ differences among sexes, age classes, or manners of death, we sought to verify that metabolic or dietary differences between these different groups do not affect $\varepsilon^{*}$ values. Such comparisons are often missing from tissue fractionation and enrichment studies. Analyses were performed using JMP version 5.0.1a for Macintosh with the significance of all tests set at $\alpha \leq 0.05$.

\section{Results}

Mean and standard deviations for each species are presented in Table 3, and raw $\delta^{13} \mathrm{C}, \delta^{15} \mathrm{~N}$, and $\varepsilon^{*}$ values are available in ESM Table S1. Patterns of apparent enrichment varied little within the Strepsirrhini (Fig. 2) and Haplorrhini (Fig. 3). Across primates, the $\varepsilon^{13 *}$ collagen-keratin, $\varepsilon^{13 *}$ collagen-muscle, $\varepsilon^{13 *}$ muscle-keratin and $\varepsilon^{13 *}$ carbonate-collagen values did not differ $(p>0.05)$. Whereas, the $\varepsilon^{15 *}$ collagen-keratin and $\varepsilon^{15 *}$ muscle-keratin values also did not differ $(p>0.05), \varepsilon^{15 *}$ collagen-muscle values did $(t=-2.42$, $d f=18, p=0.027$ ); however, this result was driven by two Eulemur and Microcebus individuals. The removal of these two individuals resulted in no overall difference among species for $\varepsilon^{15 *}$ collagen-muscle $(p>0.05)$.

We found small but significant variation among habitat types for both carbon and nitrogen $\varepsilon^{*}$ collagen-keratin values (carbon: $F_{2,82}=3.36, p=0.040$; nitrogen: $F_{2,81}=6.73$, $p=0.020$ ). Captive animals had significantly larger $\varepsilon^{*}$ collagen-keratin values than those from moist habitats (Table 4). Our results for $\varepsilon^{15 *}$ collagen-muscle values showed a similar pattern $\left(F_{2,44}=7.03, p=0.0023\right)$, but $\varepsilon^{13}{ }^{13}$ collagen-muscle values did not differ significantly among habitat types $(p>0.05)$. Mean $\varepsilon^{13 *}$ muscle-keratin and $\varepsilon^{13} *$ carbonate-collagen values also did not differ significantly among habitats.

With the exception of $\varepsilon^{13 *}$ collagen-muscle, $\varepsilon^{*}$ values between proteinaceous tissues did not correlate with body size $(p>0.05 ;$ Table 5). If we excluded two captive Microcebus individuals, the relationship between $\varepsilon^{13} *$ collagen-muscle and body size was insignificant $\left(r^{2}=0.06\right.$, $p=0.10)$. The relationship between $\varepsilon^{13} *$ carbonate-collagen and body mass was significant $\left(r^{2}=0.031, p=0.038\right.$; Fig. 4; Table 5). However, because the slope is near 0 and the $r^{2}$ value is low, we suspect that this result is an artifact of sample size. The range in $\varepsilon^{13 *}$ carbonate-collagen values for the smallest and largest species (Microcebus spp. and Gorilla gorilla) are similar (4.5-6.9 and 5.5-7.1\%o, respectively), and the lowest and highest $\varepsilon^{13 *}$ carbonate-collagen values, 3.6 and $8.6 \%$, come from two similar-sized species, $P$. badius and A. palliata (Tables 2 and 3 ).

Finally, $\varepsilon^{*}$ values did not differ among males and females $(p>0.05$; ESM Table S2), manner of death $(p>0.05$; ESM Table S3), or age class $(p>0.05$; ESM Table S4). Given the overall consistency of our results, we combined data from all individuals and calculated mean primate $\varepsilon^{*}$ values between all proteinaceous tissues, and between carbonate and collagen (Table 6).

\section{Discussion}

Variation in $\varepsilon^{*}$ values among proteinaceous tissues

We expected some variation based on differences in amino acid compositions, but that such differences would be small and consistent across taxa. In line with our expectations, we found small $(\leq 1 \%) \varepsilon^{*}$ values between collagen and muscle, collagen and keratin, and muscle and keratin for both carbon and nitrogen (Table 6). These mean values are smaller than the majority of the $\Delta$ values reported for captive or wild animals (Table 1). It appears that because each tissue is composed of multiple AAs, the effects of isotopic differences among specific AAs are minimized. For example, relatively ${ }^{13} \mathrm{C}$-enriched glycine in collagen, serine, and cysteine in keratin, and glutamate in muscle may be driving similar $\delta^{13} \mathrm{C}$ values in all three tissues (Fig. 1). O'Connell et al. (2001) suggest that the relatively elevated levels of serine and threonine in keratin (6-7\% vs. $\sim 2 \%$ in collagen) tend to lower keratin $\delta^{15} \mathrm{~N}$ values relative to collagen. The ${ }^{15} \mathrm{~N}$-enriched glutamate in muscle may increase its $\delta^{15} \mathrm{~N}$ values relative to keratin.

Variation in $\varepsilon^{13} *$ carbonate-collagen

We had anticipated that differences in diet (e.g., $\delta^{13} \mathrm{C}$ differences in dietary sources, differences in 


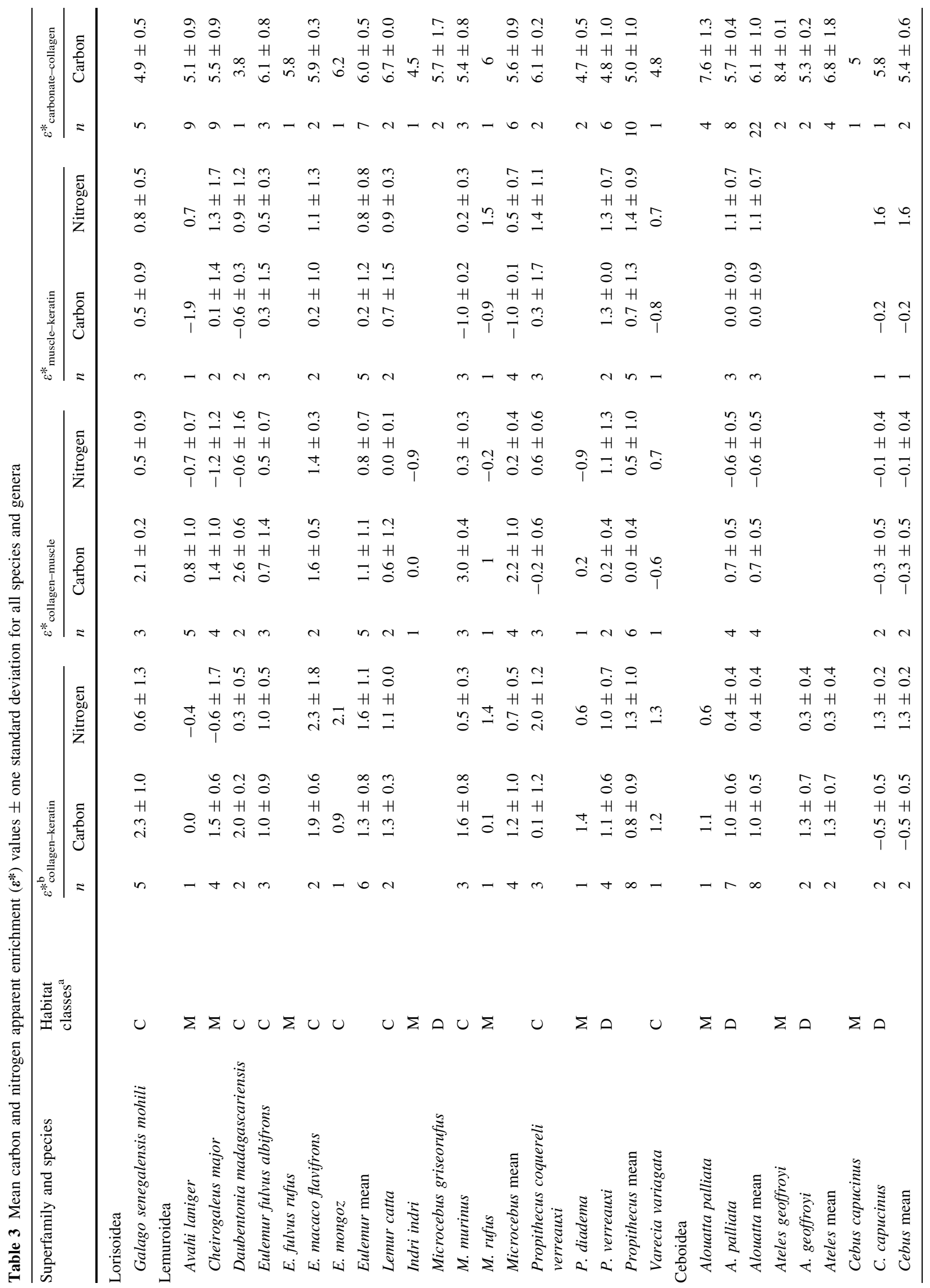




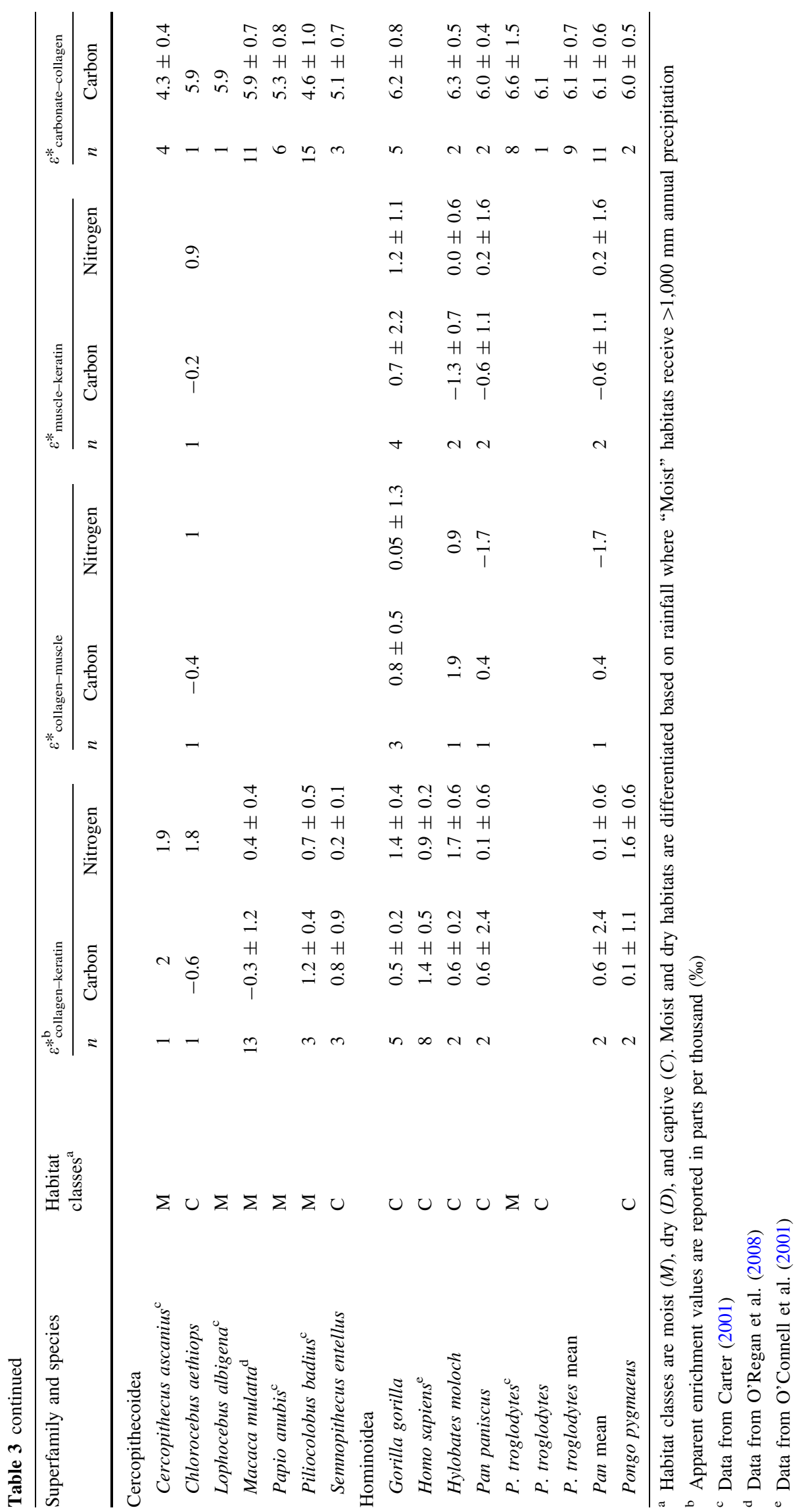




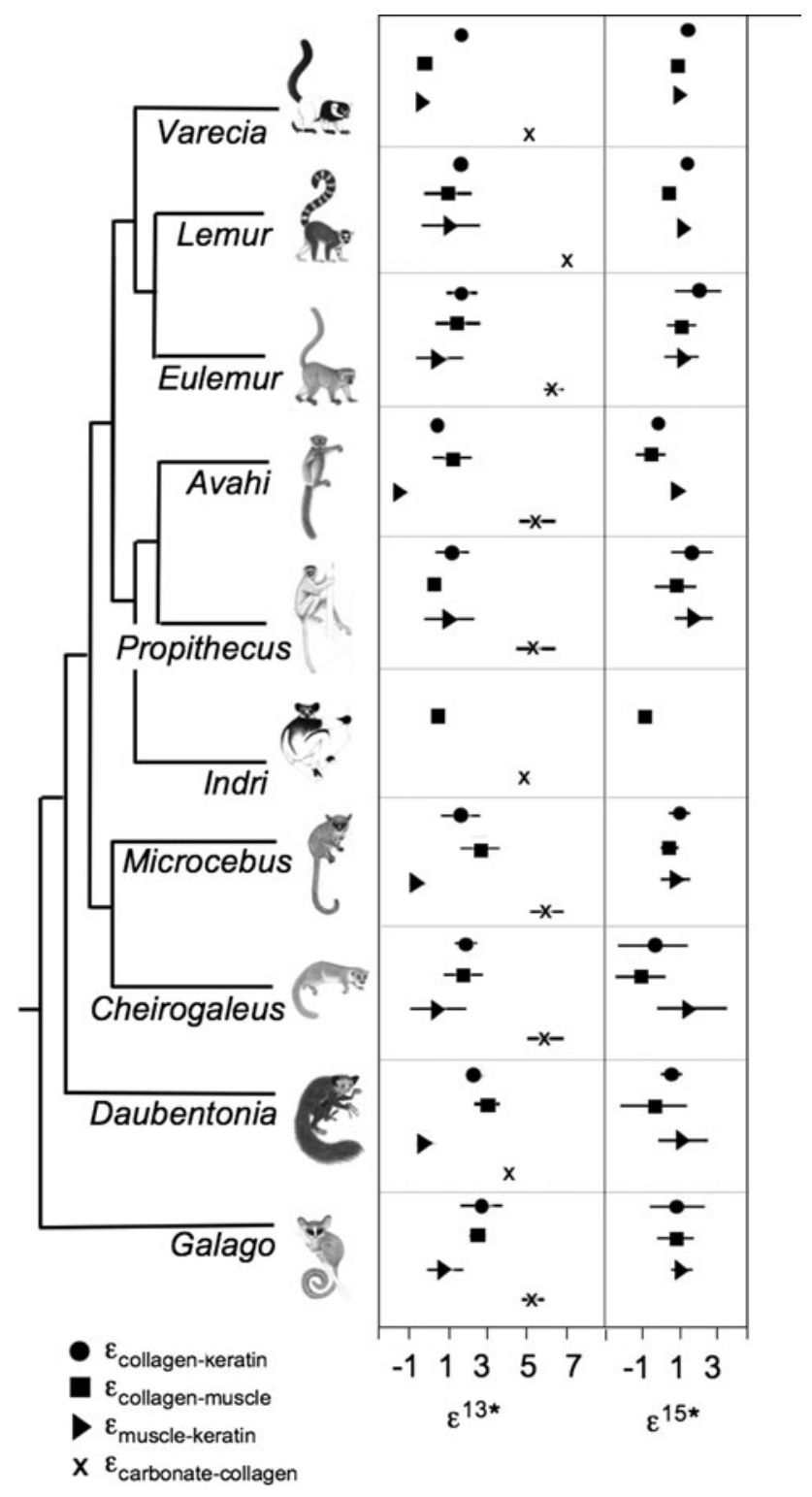

Fig. 2 Mean $\varepsilon^{*}$ collagen-keratin, $\varepsilon^{*}$ collagen-muscle, $\varepsilon^{*}$ muscle-keratin, and $\varepsilon^{*}$ carbonate-collagen, for carbon $\left(\varepsilon^{13}\right)$ and nitrogen $\left(\varepsilon^{15 *}\right) \pm 1$ standard deviation for each strepsirrhine genus. Phylogeny based on Orlando et al. (2008). Illustrations by Stephen D. Nash/Conservation International, used with permission

herbivory vs. faunivory), and digestive physiology (e.g., degree of fermentation) would lead to differences in $\varepsilon^{13 *}$ carbonate-collagen. Our results, however, suggest that all primates have comparable $\varepsilon^{13 *}$ carbonate-collagen values regardless of variation in the variables that covary with diet and digestive physiology such as phylogeny, body size, and habitat. Our mean $\varepsilon^{13 *}$ carbonate-collagen value of $5.6 \%$ for primates is similar to the mean fractionation factor $\left(\Delta_{\text {carbonate-collagen }}\right)$ for wild omnivores $(5.5 \%)$, captive omnivorous rodents fed mixed and uniform diets (5.5 and $5.4 \%$, respectively), and captive pigs fed uniform diets
(6.0\%); Table 1$)$. The mean primate $\varepsilon^{13 *}$ carbonate-collagen value is larger than the $\Delta_{\text {carbonate-collagen }}$ value reported for carnivores $(3.0 \%)$, and smaller than the reported values for both wild ruminant and non-ruminant herbivores $(9.0$ and $7.8 \%$, respectively; Table 1). ${ }^{1}$ Based on the consistency of our results, we conclude that (1) $\delta^{13} \mathrm{C}$ values for dietary protein did not differ substantially from whole diet $\delta^{13} \mathrm{C}$ values for either captive or wild primates, and (2) that microbial fermentation, to the extent that it occurred in the primates in our study, failed to significantly label the blood pool with ${ }^{13} \mathrm{C}$-enriched bicarbonate, irrespective of differences in habitat, gut physiology or body size.

\section{Diet}

We had anticipated that more herbivorous primates would have larger $\varepsilon^{13 *}$ carbonate-collagen values than more faunivorous primates. We found some variation but no consistent trends. We found no differences in $\varepsilon^{13 *}$ carbonate-collagen values with body size, despite probable dietary differences between the smallest primates, Galago and Microcebus spp., which likely consumed more insect matter, and the largest primates, Gorilla, Pan, and Pongo, which likely consumed more vegetation. A single aye-aye (Daubentonia madagascariensis), which relies largely on invertebrate prey, had a carnivore-like $\varepsilon^{13 *}$ carbonate-collagen value of $3.7 \%$. However, $\varepsilon^{13 *}$ carbonate-collagen values for the whitefaced capuchin (Cebus capucinus), which also consumes animal matter, resembled the overall primate mean (5.0 and $5.8 \%$ in dry and moist habitat, respectively). Our results likely reflect underlying dietary similarities among all primate species. In spite of apparent differences in the consumption of animal matter, all primates have a predominantly vegetarian diet (Milton 1987). These results agree with the recent findings of Smith et al. (2010), who showed that collagen $\delta^{13} \mathrm{C}$ values did not differ between male and female chimpanzees despite observations that males consumed substantially greater amounts of red colobus meat. These authors speculated that either meat consumption did not noticeably affect male collagen $\delta^{13} \mathrm{C}$ values, or that consumption of termites elevated female $\delta^{13} \mathrm{C}$ values (Smith et al. 2010).

With the exception of a few $M$. mulatta individuals (O'Regan et al. 2008; ESM Table S1), none of the wild primates in our study ate $\mathrm{C}_{4}$ or marine foods (mean $\delta^{13} \mathrm{C}$ apatite $=-16.7 \% \pm 1.4, \quad n=105 ;$ mean $\delta^{13} \mathrm{C}$ collagen $=-22.1 \% \pm \pm 1.5, n=110)$. Conversely, the majority

\footnotetext{
${ }^{1}$ We acknowledge that the observed difference between primates and non-ruminant herbivores may stem entirely from a lack of broad comparative data. Non-ruminant data are derived from equids and hippos, two groups of herbivores with substantial methane production rates (Crutzen et al. 1986), and camelids, which have $\Delta_{\text {carbonate-collagen }}$ values comparable to ruminants.
} 


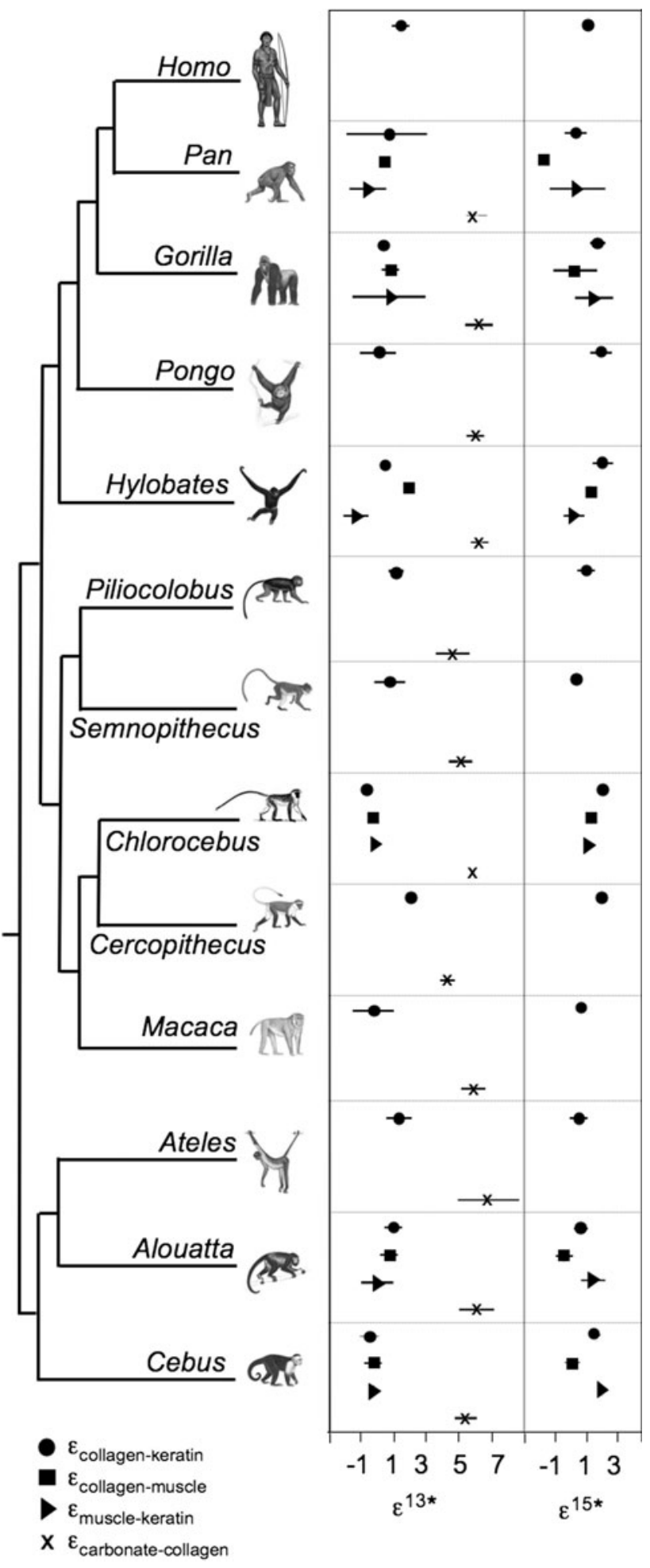

Fig. 3 Mean $\varepsilon^{*}$ collagen-keratin, $\varepsilon^{*}$ collagen-muscle, $\varepsilon^{*}$ muscle-keratin, and $\varepsilon^{*}$ carbonate-collagen for carbon $\left(\varepsilon^{13 *}\right)$ and nitrogen $\left(\varepsilon^{15 *}\right) \pm 1$ standard deviation for each haplorrhine genus. Phylogeny based on (Groves 2001). Homo sapiens data from O'Connell et al. (2001), Macaca mulatta data from O'Regan et al. (2008), and P. badius, Cercopithecus ascanius, and wild Pan troglodytes data from Carter (2001). Illustrations by Stephen D. Nash/Conservation International, used with permission of our captive primates appear to have incorporated some $\mathrm{C}_{4}$ foods into their diets (mean $\delta^{13} \mathrm{C}$ apatite $=$ $-12.7 \% \pm 1.6, n=36$; mean $\delta^{13} \mathrm{C}$ collagen $=-18.5 \%$ $\pm 1.8, n=45$; ESM Table S1). However, despite this addition of $\mathrm{C}_{4}$ foods, $\varepsilon^{13 *}$ carbonate-collagen values for captive and wild primates do not differ (Table 4). We cannot assess dietary composition in the captive primates quantitatively. Nevertheless, our results suggest that protein and whole diet $\delta^{13} \mathrm{C}$ values did not differ substantially for captive animals. We note that the laboratory diets for some of the controlled feeding studies listed in Table 1 were designed to maximize possible isotopic differences among tissues. The majority of these diets were not designed to maintain healthy individuals, and most laboratory animals were sacrificed at a young age. In contrast, captive primates are given balanced diets designed to maintain their health and increase their longevity. As a result, diets for captive primates tend to be much more isotopically restricted than experimental laboratory diets consisting of mixed $\mathrm{C}_{3}, \mathrm{C}_{4}$, and marine components. In line with this reasoning, the range in captive primate $\varepsilon^{13 *}$ carbonate-collagen values $\left(3.8-7.1 \%\right.$ ) is similar to the range in $\Delta_{\text {carbonate-collagen }}$ values reported for captive animals fed isotopically homogenous diets $(4.5-6.7 \%$ ), but much smaller than the ranges reported for captive animals fed experimental diets incorporating a mix of $\mathrm{C}_{3}, \mathrm{C}_{4}$, and marine components ( -0.8 to $11.3 \%$, Table 1$)$.

Physiology and fermentation

Despite differences in diet, all primates ferment their food to some degree. More folivorous, gumnivorous, and faunivorous primates break down the structural carbohydrates in vegetation, plant exudates, and arthropod exoskeletons, respectively (Lambert 1998). Nevertheless, carbohydrate fermentation in primates does not appear to produce enough methane and associated ${ }^{13} \mathrm{C}$-enriched $\mathrm{CO}_{2}$ to significantly label blood bicarbonate or bone carbonate. We might have anticipated that taxa with long measured retention times such as Gorilla, Pongo, Lophocebus, Chlorocebus, and Cercopithecus might have larger $\varepsilon^{13 *}$ carbonate-collagen values (Kleiber 1961; Langer 1987). Increased retention time may increase methane production during fermentation, and the degree to which ${ }^{13} \mathrm{C}$-enriched $\mathrm{CO}_{2}$ diffuses into the blood (Kleiber 1961; Langer 1987). Our results do not support these expectations. Mean $\varepsilon^{13 *}$ carbonate-collagen values for the hominoids $(6.2$ and $6.0 \%$, respectively), and the cercopithecines (5.9, 5.9, and 4.3\%o, respectively; Table 1) are comparable to or only slightly larger than our mean primate $\varepsilon^{13 *}$ carbonate-collagen value $(5.6 \%)$. Conversely, the $\varepsilon^{13 *}$ carbonate-collagen value for Ateles geoffroyi, which has a fast retention time (6.8\%), is substantially larger than the average primate value. 
Table 4 Mean carbon and nitrogen apparent enrichment $\left(\varepsilon^{*}\right)$ values \pm one standard deviation for primates living in dry, moist, and captive settings

\begin{tabular}{llllcrrrr}
\hline & $n$ & $\varepsilon^{* a}$ collagen-keratin & $n$ & $\varepsilon_{\text {collagen-muscle }}^{*}$ & $n$ & $\varepsilon_{\text {muscle-keratin }}^{*}$ & $n$ & $\varepsilon_{\text {carbonate- collagen }}^{*}$ \\
\hline Carbon & & & & & & & \\
Dry & 15 & $0.8 \pm 0.8 \mathrm{AB}$ & 9 & $0.3 \pm 0.6 \mathrm{~A}$ & 6 & $0.4 \pm 0.9 \mathrm{~A}$ & 29 & $5.5 \pm 0.8 \mathrm{~A}$ \\
Moist & 25 & $0.4 \pm 1.2 \mathrm{~B}$ & 12 & $0.9 \pm 0.9 \mathrm{~A}$ & 4 & $-0.7 \pm 1.2 \mathrm{~A}$ & 75 & $5.5 \pm 1.2 \mathrm{~A}$ \\
Captive & 43 & $1.1 \pm 1.0 \mathrm{~A}$ & 25 & $1.3 \pm 1.2 \mathrm{~A}$ & 30 & $-0.05 \pm 1.3 \mathrm{~A}$ & 35 & $5.7 \pm 0.8 \mathrm{~A}$ \\
Nitrogen & & & & & & & \\
Dry & 15 & $0.7 \pm 0.6 \mathrm{AB}$ & 8 & $-0.1 \pm 1.0 \mathrm{AB}$ & 6 & $1.3 \pm 0.6 \mathrm{~A}$ & n.a. \\
Moist & 24 & $0.3 \pm 0.9 \mathrm{~B}$ & 12 & $-0.8 \pm 0.8 \mathrm{~B}$ & 4 & $1.2 \pm 1.1 \mathrm{~A}$ & n.a. \\
Captive & 43 & $1.1 \pm 0.9 \mathrm{~A}$ & 25 & $0.3 \pm 0.9 \mathrm{~A}$ & 30 & $0.8 \pm 0.8 \mathrm{~A}$ & & n.a. \\
\hline
\end{tabular}

n.a. Not applicable

${ }^{\text {a }}$ Apparent enrichment values are reported in parts per thousand (\%o). Mean $\varepsilon^{*}$ values in the same homogenous subset are given the same letters $(\alpha$ set at 0.05$)$

Table 5 Regression results for $\varepsilon^{*}$ versus the natural logarithm of body mass

\begin{tabular}{lrrlllll}
\hline & $n$ & $\begin{array}{l}\text { Carbon } \\
r^{2}\end{array}$ & $p$ & $n$ & $\begin{array}{l}\text { Nitrogen } \\
r^{2}\end{array}$ & $p$ \\
\hline Collagen-keratin & 83 & 0.046 & 0.051 & 82 & 0.021 & 0.19 \\
Collagen-muscle & 46 & 0.110 & 0.015 & 45 & -0.023 & 0.98 \\
Muscle-keratin & 36 & -0.024 & 0.670 & 36 & -0.019 & 0.55 \\
Carbonate-collagen & 140 & 0.031 & 0.038 & n.a. & n.a. & n.a. \\
\hline
\end{tabular}

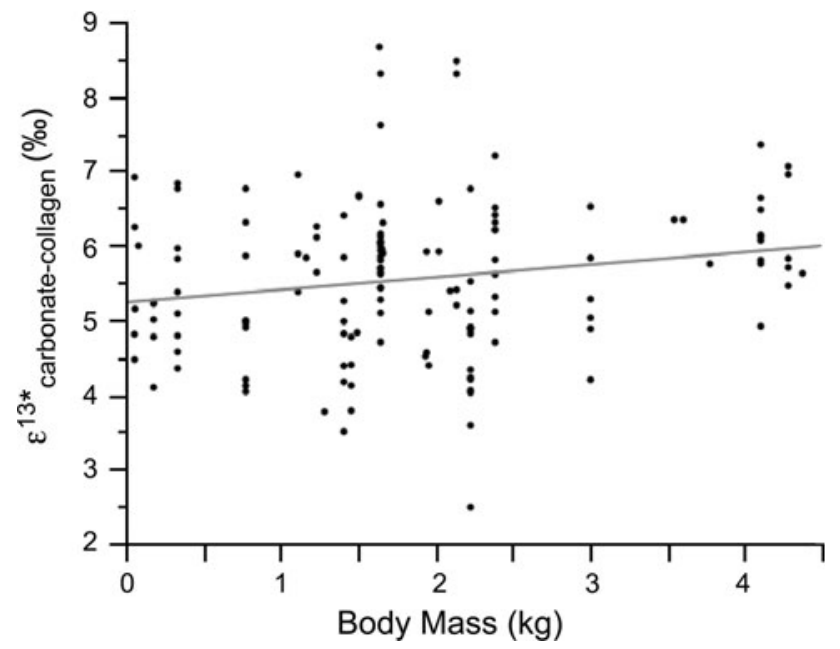

Fig. 4 The relationship between the natural $\log$ of body mass $(\mathrm{kg})$ and $\varepsilon^{13 *}$ carbonate-collagen $\left(\varepsilon^{*}\right.$ carbonate-collagen $=5.24+0.163 * \ln$ body mass, $\left.r^{2}=0.031, p=0.038\right)$

We had also anticipated that colobine monkeys, represented by $P$. badius and Semnopithecus entellus, and the ateline monkey $A$. palliata, would have higher $\varepsilon^{13} *$ carbonate-collagen values associated with fermentation in their enlarged stomachs and caeca, respectively. Our results do not support these expectations. Despite their
Table 6 Suggested $\varepsilon^{*}$ values for comparing different primate tissue types

\begin{tabular}{lcc}
\hline Tissue comparison & \multicolumn{1}{l}{$\begin{array}{l}\text { Carbon } \\
\text { Mean } \pm 1 \text { SD }(\%)\end{array}$} & $\begin{array}{l}\text { Nitrogen } \\
\text { Mean } \pm 1 \text { SD }(\%)\end{array}$ \\
\hline Collagen-keratin & $0.9 \pm 1.1$ & $0.8 \pm 0.9$ \\
Collagen-muscle & $1.0 \pm 1.1$ & $-0.1 \pm 1.0$ \\
Muscle-keratin & $-0.04 \pm 1.2$ & $0.9 \pm 0.8$ \\
Carbonate-collagen & $5.6 \pm 1.0$ & n.a. \\
\hline
\end{tabular}

potential for increased levels of methane production, both wild and captive colobine monkeys in our dataset had $\varepsilon^{13 *}$ carbonate-collagen values comparable to other primate species (Fig. 2; Tables 3 and ESM S1). Our lowest reported $\varepsilon^{13 *}$ carbonate-collagen value $(3.6 \%)$ is from a wild $P$. badius individual. This result is in agreement with the lack of methane production observed in two wild Colobus polykomos individuals (Ohwaki et al. 1974). It appears that, despite their large "ruminant-like" stomachs, colobines produce little to no methane and associated ${ }^{13} \mathrm{C}$-enriched $\mathrm{CO}_{2}$, and their digestion resembles that of small simplestomached animals rather than ruminants.

We did find a large mean $\varepsilon^{13 *}$ carbonate-collagen value for the mantled howling monkey (A. palliata) in a rainforest habitat (7.6\%o). However, we also found a large $\varepsilon^{13 *}$ carbonate-collagen value $(8.4 \%)$ for rainforest-dwelling black-handed spider monkeys (A. geoffroyi), which does not have a gut designed for extensive fermentation (Chivers and Hladik 1980). Intriguingly, these two species had comparable but lower $\varepsilon^{13}{ }^{*}$ carbonate-collagen values similar to our primate mean in a seasonally dry forest habitat (5.7 and 5.3\%o, respectively). Although A. palliata and A. geoffroyi are typically categorized as folivorous and frugivorous, respectively, both of these species have been observed to have highly variable diets (Cristóbal-Azkarate and Arroyo- 
Table 7 Comparing estimated keratin $\delta^{13} \mathrm{C}$ and $\delta^{15} \mathrm{~N}$ values with measured keratin $\delta^{13} \mathrm{C}$ and $\delta^{15} \mathrm{~N}$ values from wild and captive primate populations

\begin{tabular}{|c|c|c|c|c|c|c|c|}
\hline & Isotope & $n$ & $\begin{array}{l}\text { Mean } \\
\text { collagen } \pm 1 \text { SD }(\%)\end{array}$ & $\begin{array}{l}\text { Estimated } \\
\text { keratin }(\% 0)\end{array}$ & $\begin{array}{l}\text { Measured mean } \\
\text { keratin } \pm 1 \mathrm{SD}(\% \mathrm{o})\end{array}$ & $n$ & Source \\
\hline \multicolumn{8}{|l|}{ Wild } \\
\hline Cercopithecus ascanius & Carbon & 3 & $-21.1 \pm 0.3$ & -22.0 & $-22.7 \pm 0.2$ & 2 & 1 \\
\hline Lophocebus albigena & Carbon & 1 & -20.8 & -21.7 & $-21.7 \pm 0.2$ & 2 & 1 \\
\hline Pan troglodytes & Carbon & 9 & $-21.5 \pm 0.7$ & -22.4 & -21.8 & 1 & 1 \\
\hline Piliocolobus badius & Carbon & 12 & $-21.0 \pm 0.5$ & -21.9 & $-22.5 \pm 0.4$ & 6 & 1 \\
\hline \multirow[t]{2}{*}{ Propithecus verreauxi } & Carbon & 7 & $-21.2 \pm 0.7$ & -22.1 & $-23.1 \pm 1.0$ & 5 & 2 \\
\hline & Nitrogen & 7 & $7.3 \pm 0.7$ & 6.5 & $6.3 \pm 1.2$ & 5 & 2 \\
\hline \multicolumn{8}{|l|}{ Captive } \\
\hline \multirow[t]{2}{*}{ Pan paniscus } & Carbon & 1 & -20.2 & -21.1 & $-20.7 \pm 1.2$ & 3 & 2 \\
\hline & Nitrogen & 1 & 8.3 & 7.5 & $8.0 \pm 2.1$ & 3 & 2 \\
\hline Semnopithecus entellus & Carbon & 3 & $-16.5 \pm 0.5$ & -17.4 & $-17.2 \pm 0.7$ & 2 & 2 \\
\hline
\end{tabular}

Estimated keratin isotope values were calculated by applying mean $\varepsilon^{*}$ collagen-keratin values (Table 6 ) to measured collagen isotope values Data are from (1) Carter (2001); (2) this study

Rodríguez 2007; González-Zamora et al. 2009). It is possible that they shared dietary items in the rainforest habitat that were rich in non-starch polysaccharides (NPS), the breakdown of which has been associated with increased methane production in pigs (Jensen 1996). Alternatively, it is possible that the two species shared a food item with elevated $\delta^{13} \mathrm{C}$ values, (e.g., a CAM plant) which increased their whole diet $\delta^{13} \mathrm{C}$ values without affecting their dietary protein. This result is interesting and suggests that future work examining species-specific $\varepsilon^{13 *}$ carbonate-collagen values with varying diets could be enlightening. Nevertheless, these are the only two taxa that demonstrate substantial differences in apparent enrichment values among habitats. For example, $\varepsilon^{13 *}$ carbonate-collagen values for $C$. capucinus from the same two habitats are much more similar (5.8 and 5.0\% in the moist and dry habitats, respectively). Pan troglodytes exhibits similar $\varepsilon^{13} *_{\text {carbonate-collagen values among captive }}$ and moist habitats (6.1 and 6.6\%o, respectively), and all Microcebus taxa have similar $\varepsilon^{13} *$ carbonate-collagen values in all three habitat types $(5.4,6.0$, and $5.7 \%$ in captive, moist, and dry habitats, respectively). Based on the data available, we therefore advocate using our mean primate $\varepsilon^{13 *}$ carbonate-collagen value (5.6\%) to compare collagen and carbonate $\delta^{13} \mathrm{C}$ values among primates.

Verification of $\varepsilon^{*}$ values

An important outcome of our analyses is the ability to determine mean apparent enrichment values that can be used in existing and future comparisons based on mixed tissues or samples. To validate primate $\varepsilon^{*}$ values, we estimated keratin $\delta^{13} \mathrm{C}$ and $\delta^{15} \mathrm{~N}$ values by applying mean $\varepsilon^{*}$ collagen-keratin values to measured collagen $\delta^{13} \mathrm{C}$ and $\delta^{15} \mathrm{~N}$ values for wild primate populations not included in our apparent enrichment dataset. We then compared these estimated keratin values to measured keratin values from different individuals within the same wild populations (Table 7). Compellingly, the range of estimated keratin isotope values closely matches the measured keratin isotope values.

\section{Conclusions}

We have presented data on the apparent isotopic enrichment in carbon and nitrogen isotopes between collagen and keratin, collagen and muscle, and apatite carbonate and collagen in primates. Primates are an extremely diverse group of animals in terms of diet, body size, and gut morphology, yet $\varepsilon^{*}$ values are relatively invariant across the order. We recommend applying our calculated mean $\varepsilon^{*}$ values when comparing isotope values from different modern primate tissues. Additionally, using these mean apparent enrichment values will be essential for accurately predicting how the isotopic niches of extinct primates compare with those of modern extant primates.

Acknowledgments We are grateful to institutions that donated cadaveric tissues to the Department of Anthropology, UC Santa Cruz (Oklahoma Zoo, San Francisco Zoo, Ft. Worth Zoo, Milwaukee Zoo, Humboldt Zoo, Chaffee Zoological Gardens, Santa Anna Zoo, Duke Lemur Center, The Gorilla Foundation, The Gibbon Conservation Center). We thank M.J. Schoeninger for providing raw collagen and carbonate $\delta^{13} \mathrm{C}$ values for wild African herbivores. We are also grateful to the following individuals for samples and assistance: M.R. Blanco, A.D. Cunningham, K.A. Dingess, P. Dolhinow, K.E. Glander, L.R. Godfrey, W. McCandless, S. Matarazzo, I. Mesen, A. Mootnick, G. Pieraccini, M.A. Ramsier, R.B. Segura, C. Underwood, E.R. Vogel, P.C. Wright, and S. Zehr. We thank two anonymous reviewers for useful comments on earlier versions of this manuscript. The 
importation and use of animal tissues was approved by the United States Fish and Wildlife Service (CITES permit nos. 06US130146/9 and 007319). Funding was provided by the David and Lucile Packard Foundation. This is DLC publication \#1181.

Open Access This article is distributed under the terms of the Creative Commons Attribution Noncommercial License which permits any noncommercial use, distribution, and reproduction in any medium, provided the original author(s) and source are credited.

\section{References}

Ambrose SH, DeNiro MJ (1986) The isotopic ecology of East African mammals. Oecologia 69:395-406

Ambrose SH, Norr L (1993) Experimental evidence for the relationship of the carbon isotope ratios of whole diet and dietary protein to those of bone collagen and carbonate. In: Lambert JB, Grupe G (eds) Prehistoric human bone-archaeology at the molecular level. Springer, Berlin, pp 1-37

Ambrose SH, Butler BM, Hanson DB, Hunter-Anderson RL, Krueger HW (1997) Stable isotopic analysis of human diet in the Marianas Archipelago, Western Pacific. Am J Phys Anthropol 104:343-361

Bergström J, Furst P, Noree L-O, Vinnars E (1974) Intracellular free amino acid concentration in human muscle tissue. J Appl Physiol 36:693-697

Bininda-Emonds ORP, Cardillo M, Jones KE, MacPhee RDE, Beck RMD, Grenyer R, Price SA, Vos RA, Gittleman JL, Purvis A (2007) The delayed rise of present-day mammals. Nature 446:507-512. doi:10.1038/nature05634

Boesch C, Boesch-Achermann H (2000) The Chimpanzees of the Taï Forest: behavioral ecology and evolution. Oxford University Press, Oxford

Carter M (2001) Sensitivity of stable isotopes $\left({ }^{13} \mathrm{C},{ }^{15} \mathrm{~N}\right.$, and $\left.{ }^{18} \mathrm{O}\right)$ in bone to dietary specialization and niche separation among sympatric primates in Kibale National Park, Uganda. $\mathrm{PhD}$ dissertation, University of Chicago, Chicago

Cerling TE, Harris JM (1999) Carbon isotope fractionation between diet and bioapatite in ungulate mammals and implications for ecological and paleoecological studies. Oecologia 120:247-363. doi: $10.1007 / \mathrm{s} 004420050868$

Chapman CA, Chapman LJ, Gillespie TR (2002a) Scale issues in the study of primate foraging: red colobus of Kibale National Park. Am J Phys Anthropol 117:349-363. doi:10.1002/ajpa.10053

Chapman CA, Chapman LJ, Cords M, Gathua JM, Gautier-Hion A, Lambert JA, Rode K, Tutin CEG, White LJT (2002b) Variation in the diets of Cercopithecus species: differences within forests, among forests, and across species. In: Glenn M, Cords M (eds) The Guenons: diversity and adaptation in African monkeys. Kluwer/Plenum, New York, pp 325-350

Chivers DJ, Hladik CM (1980) Morphology of the gastrointestinal tract in primates: comparisons with other mammals in relation to diet. J Morphol 166:337-386

Codron D, Luyt J, Lee-Thorp JA, Sponheimer M, de Ruiter D, Codron J (2005) Utilization of savanna-based resources by PlioPleistocene baboons. S Afr J Sci 101:245-248

Codron D, Lee-Thorp JA, Sponheimer M, de Ruiter D, Codron J (2006) Inter- and intrahabitat dietary variability of chacma baboons (Papio ursinus) in South African savannas based on fecal $\delta^{13} \mathrm{C}, \delta^{15} \mathrm{~N}$, and $\% \mathrm{~N}$. Am J Phys Anthropol 129:204-214. doi:10.1002/ajpa.20253

Corr LT, Sealy JC, Horton MC, Evershed RP (2005) A novel marine dietary indicator utilizing compound-specific bone collagen amino acid $\delta^{13} \mathrm{C}$ values of ancient humans. J Archaeol Sci 32:321-330. doi:10.1016/j.jas.2004.10.002

Cristóbal-Azkarate J, Arroyo-Rodríguez V (2007) Diet and activity pattern of howler monkeys (Alouatta palliata) in Los Tuxtlas, Mexico: effects of habitat fragmentation and implications for conservation. Am J Primatol 69:1013-1029. doi:10.1002/ajp.20420

Crutzen PJ, Aselmann I, Seiler W (1986) Methane production by domestic animals, wild ruminants, and other herbivore fauna and humans. Tellus Series B 38:271-284

DeNiro MJ, Epstein S (1978) Influence of diet on the distribution of carbon isotopes in animals. Geochim Cosmochim Acta 42:495-506

DeNiro MJ, Epstein S (1981) Influence of diet on the distribution of nitrogen isotopes in animals. Geochim Cosmochim Acta 45:341-351

Fleagle JG (1999) Primate adaptation and evolution, 2nd edn. Academic, San Diego

Fogel ML, Tuross N (2003) Extending the limits of paleodietary studies of humans with compound specific carbon isotope analysis of amino acids. J Archaeol Sci 30:535-545. doi: 10.1016/j.jas.2008.06.002

Fourie NH, Lee-Thorp JA, Ackermann RR (2008) Biogeochemical and craniometric investigation of dietary ecology, niche separation, and taxonomy of Plio-Pleistocene cercopithecoids from the Makapansgat Limeworks. Am J Phys Anthropol 135:121-135. doi:10.1002/ajpa.20713

Fox-Dobbs K, Bump JK, Peterson RO, Fox DL, Koch PL (2007) Carnivore-specific stable isotope variables and variation in the foraging ecology of modern and ancient wolf populations: case studies from Isle Royale, Minnesota, and La Brea. Can J Zool 85:458-471. doi:10.1139/Z07-018

Génin F (2008) Life in unpredictable environments: first investigation of the natural history of Microcebus grseorufus. Int J Primatol 29:303-321. doi:10.1007/s10764-008-9243-z

González-Zamora A, Arroyo-Rodríguez V, Chaves OM, Sánchez-Lopez S, Stoner KE, Riba-Hernández P (2009) Diet of spider monkeys (Ateles geoffroyi) in Mesoamerica: current knowledge and future directions. Am J Primatol 71:8-20. doi:10.1002/ajp.20625

Groves C (2001) Primate taxonomy. Smithsonian Institution Press, Washington DC

Hare PE, Estep MLF (1983) Carbon and nitrogen isotopic composition of amino acids in modern and fossil collagens. Year B Carnegie Inst Wash 82:410-414

Hare PE, Fogel ML, Stafford TW, Mitchell AD, Hoering TC (1991) The isotopic composition of carbon and nitrogen in individual amino acids isolated from modern and fossil proteins. J Archaeol Sci 18:277-292

Hedges REM (2003) On bone collagen-apatite-carbonate isotopic relationships. Int J Osteoarchaeol 13:66-79. doi:10.1002/oa.660

Howland MR, Corr LT, Young SMM, Jones V, Jim S, van der Merwe NJ, Mitchell AD, Evershed RP (2003) Expression of the dietary isotope signal in the compound-specific $\delta^{13} \mathrm{C}$ values of pig bone lipids and amino acids. Int $\mathrm{J}$ Osteoarchaeol 13:54-65. doi: 10.1002/oa.658

Hrdy D, Baden HP (1973) Biochemical variation of hair keratins in man and non-human primates. Am J Phys Anthropol 39:19-24

Jensen BB (1996) Methanogenesis in monogastric animals. Environ Monit Assess 42:99-112

Jim S, Ambrose SH, Evershed RP (2004) Stable carbon isotopic evidence for differences in the dietary origin of bone cholesterol, collagen and apatite: implications for their use in palaeodietary reconstruction. Geochim Cosmochim Acta 68:61-72. doi:10.1016/ S0016-7037(03)00216-3

Jim S, Jones V, Ambrose SH, Evershed RP (2006) Quantifying dietary macronutrient sources of carbon for bone collagen biosynthesis using natural abundance stable carbon isotope analysis. Br J Nutr 95:1055-1062. doi:10.1079/BJN20051685 
Kay RNB, Davies AG (1994) Digestive physiology. In: Davies AG, Oates JF (eds) Colobine monkeys: their ecology, behavior and evolution. Cambridge University Press, Cambridge, pp 229-248

Kellner CM, Schoeninger M (2007) A simple carbon isotope model for reconstructing prehistoric human diet. Am J Phys Anthropol 133:1112-1127. doi:10.1002/ajpa.20618

Kleiber M (1961) The fire of life: an introduction to animal energetics. Wiley, New York

Koch PL, Tuross N, Fogel ML (1997) The effects of sample treatment and diagenesis on the isotopic integrity of carbonate in biogenic hydroxylapatite. J Archaeol Sci 24:417-429

Krueger HW, Sullivan CH (1984) Models for carbon isotope fractionation between diet and bone. In: Turnland JF, Johnson PE (eds) Stable isotopes in nutrition. American Chemical Society, Washington, pp 205-222

Lambert JE (1998) Primate digestion: interactions among anatomy, physiology, and feeding ecology. Evol Anthropol 7:8-20

Langer P (1987) Evolutionary patterns of Perissodactyla and Artiodactyla (Mammalia) with different types of digestion. Z Syst Evolut-forsch 25:212-236

Lee-Thorp JA, Sealy JC, van der Merwe NJ (1989) Stable carbon isotope ratio differences between bone collagen and bone apatite, and their relationship to diet. J Archaeol Sci 16:585-599

Maddison WP, Maddison DR (2008) A modular system for evolutionary analysis, version 2.5. http://www.mesquiteproject.org. Accessed 05 May 2009

Martínez del Rio C, Wolf BO (2005) Mass-balance models for animal ecology. In: Stark JM, Wang $\mathrm{T}$ (eds) Physiological and ecological adaptations to feeding in vertebrates. Science, Enfield, pp 141-174

Martínez del Rio C, Wolf N, Carleton SA, Gannes LZ (2009) Isotopic ecology ten years after a call for more laboratory experiments. Biol Rev Camb Philos Soc 84:91-111. doi:10.1111/j.1469185X.2008.00064.X

McClelland JW, Montoya JP (2002) Trophic relationships and the nitrogen isotopic composition of amino acids in plankton. Ecology 83:2173-2180

Metges C, Kempe K, Schmidt H-L (1990) Dependence of the carbonisotope contents of breath, carbon-dioxide, milk, serum and rumen fermentation products on the $\delta^{13} \mathrm{C}$ value of food in dairycows. Br J Nutr 63:187-196

Milton K (1987) Primate diets and gut morphology: implications for human evolution. In: Harris M, Ross EB (eds) Food and evolution: toward a theory of human food habits. Temple University Press, Philadelphia, pp 93-116

Milton K, May ML (1976) Body weight, diet and home range area in primates. Nature 259:459-462

Nardoto GB, de Godoy PB, de Barros Ferraz ES, Ometto JPHB, Martinelli LA (2006) Stable carbon and nitrogen isotopic fractionation between diet and swine tissues. Sci Agric 63:579-582

Nelson BK, DeNiro MJ, Schoeninger MJ, De Paolo DJ, Hare PE (1986) Effects of diagenesis on strontium, carbon, nitrogen and oxygen concentration and isotopic composition of bone. Geochim Cosmochim Acta 50:1941-1949

O'Connell TC, Hedges REM, Healey MA, Simpson AHRW (2001) Isotopic comparison of hair, nail and bone: modern analyses. J Archaeol Sci 28:1247-1255. doi:10.1006/jasc.2001.0698

O'Regan HJ, Chenery C, Lamb AL, Stevens RE, Rook L, Elton S (2008) Modern macaque dietary heterogeneity assessed using stable isotope analysis of hair and bone. J Hum Evol 44:617626. doi:10.1016/j.jhevol.2008.05.001

Ohwaki K, Hungate R, Lotter L, Homann R, Maloiy G (1974) Stomach fermentation in East African colobus monkeys in their natural state. Appl Microbiol 27:713-723

Orlando L, Calvignac S, Schnebelen C, Douady CJ, Godfrey LR, Hänni C (2008) DNA from extinct giant lemurs links archaeolemurids to extant indriids. BMC Evol Biol 8:121-129. doi:10.1186/1471-2148-8-121

Passey BH, Robinoson TF, Ayliffe LK, Cerling TE, Sponheimer M, Dearing MD, Roeder BL, Ehleringer JR (2005) Carbon isotope fractionation between diet, breath $\mathrm{CO}_{2}$, and bioapatite in different mammals. J Archaeol Sci 32:1459-1470. doi: 10.1016/j.jas.2005.03.015

Popp BN, Graham BS, Olson RJ, Hannides CCS, Lott MJ, LópezIbarra GA, Galván-Magaña, Fry B (2007) Insight into the trophic ecology of yellowfin tuna, Thunnus albacares, from compoundspecific nitrogen isotope analysis of proteinaceous amino acids. In: Dawson T, Siegwolf R (eds) Stable isotopes as indicators of ecological change. Elsevier/Academic, San Diego, pp 173-190

Roth JD, Hobson KA (2000) Stable carbon and nitrogen isotopic fractionation between diet and tissue of captive red fox: implications for dietary reconstruction. Can J Zool 78:848-852

Rowe N (1996) The pictorial guide to living primates. East Hampton, Patagonias

Schoeninger MJ (2010) Toward a $\delta^{13} \mathrm{C}$ isoscape for primates. In: West JB, Bowen GJ, Dawson TE, Tu KP (eds) Isoscapes: understanding movement, pattern, and process on Earth through isotope mapping. Springer, New York, pp 319-333

Schoeninger MJ, DeNiro MJ (1982) Carbon isotope ratios of apatite from fossil bone cannot be used to reconstruct diets of animals. Nature 297:577-578

Schoeninger MJ, Iwaniec UT, Glander KE (1997) Stable isotope ratios indicate diet and habitat use in new world monkeys. Am J Phys Anthropol 103:69-83

Schulze E, Lohmeyer S, Giese W (1997) Determination of ${ }^{13} \mathrm{C} /{ }^{12} \mathrm{C}$ ratios in rumen produced methane and $\mathrm{CO}_{2}$ of cows, sheep and camels. Isotopes Environ Health Stud 33:75-79

Smith RJ, Jungers WL (1997) Body mass in comparative anatomy. J Hum Evol 32:523-559

Smith CC, Morgan ME, Pilbeam D (2010) Isotopic ecology and dietary profiles of Liberian chimpanzees. J Hum Evol 58:43-55. doi:10.1016/j.jhevol.2009.08.001

Sponheimer M, Loudon JE, Codron D, Howells ME, Pruetz JD, Codron J, de Ruiter DJ, Lee-Thorp JA (2006) Do "Savanna" chimpanzees consume $\mathrm{C}_{4}$ resources? J Hum Evol 51:128-133. doi:10.1016/j.jhevol.2006.02.002

Styring AK, Sealy JC, Evershed RP (2010) Resolving the builk $\delta^{15} \mathrm{~N}$ values of ancient human and animal bone collagen via compoundspecific nitrogen isotope analysis of contituent amino acids. Geochim Cosmochim Acta 74:241-251. doi:10.1016/j.gca.2009.09.022

Sullivan CH, Krueger DA (1981) Carbon isotope analysis of separate chemical phases in modern and fossil bone. Nature 292:333-335

Thackeray JF, Henzi SP, Brain CK (1996) Stable carbon and nitrogen isotope analysis of bone collagen in Papiocynocephalus ursinus: comparison with ungulates and Homo sapiens from southern and East African environments. S Afr J Sci 92:209-212

Tieszen LL, Fagre T (1993) Effect of diet quality and composition on the isotopic composition of respiratory $\mathrm{CO}_{2}$, bone collagen, bioapatite, and soft tissues. In: Lambert JB, Grupe G (eds) Prehistoric human bone-archaeology at the molecular level. Springer, Berlin, pp 121-155

Tieszen LL, Boutton TW, Tesdahl KG, Slade NA (1983) Fractionation and turnover of stable carbon isotopes in animal tissues: Implications for $\delta^{13} \mathrm{C}$ analysis of diet. Oecologia 57:32-37

Vogel JC (1978) Isotopic assessment of the dietary habits of ungulates. S Afr J Sci 74:298-301

West JB, Bowen GJ, Cerling TE, Ehleringer JR (2006) Stable isotopes as one of nature's ecological recorders. Trends Ecol Evol 21:408-414. doi:10.1016/j.tree.2006.04.002

Yamashita N (2002) Diets of two lemur species in different microhabitats in Beza Mahafaly special reserve, Madagascar. Int J Primatol 23:1025-1051 